\title{
METHODS APPLIED IN DETERMINING THE VARIATIONS OF STRENGTH AND STRUCTURE OF PLUTONIC ROCK MATERIAL EXPOSED TO ARTIFICIAL WEATHERING TREATMENT
}

\author{
PEKKA IHALAINEN
}

IHALAINEN, PEKKA 1993. Methods applied in determining the variations of strength and srtucture of plutonic rock material exposed to artificial weathering treatment. Bull. Geol. Soc. Finland 65, Part II, 67-76.

In this study the most significant factors determining the weathering of natural rock material proved to be the water saturation of the samples and the chemical composition of the pore water. The action of hydrolysis caused by the acidity of the pore water, combined with repeated freezing and thawing in 100\% relative humidity proved to be the most significant factor in the alteration of the strength and structure of the studied material, the Inari anorthosite. The action of these methods disintegrated the rock material more than any other weathering treatment or any other combination of the treatments used in this study.

The changes in the strength of the rock material were most reliably illustrated by the changes in tensile strength, measured by the changes in the modulus of rupture and the point load index. In several cases the standard deviations of the results exceeded the absolute changes of the corresponding parameter value. By progressing weathering, the porosity of the Inari anorthosite changed in such a way that both the frost and salt weathering increased primarily the proportion of the large pores while the hydrolysis increased the proportion of the small pores of the total porosity.

It is rather difficult to simulate in the laboratory the changes in strength and structure of building stone caused by natural weathering, since the effectiveness of the climatic and environmental factors affecting the rock surface in real conditions varies from case to case and according to the duration of the weathering action. An unweathered firm silicate rock with low porosity, such as the Inari anorthosite, has such a resistance against weathering that the necessary series of laboratory experiments to determine the changes in strength inevitably take several months.

Key words: building stone, anorthosite, weathering, mechanical properties, strenght, porosity, pore water, experimental studies, Inari, Finland.

Pekka Ihalainen, Institute of Engineering Geology, Tampere University of Technology, P.O. Box 600, 33101 Tampere Finland 


\section{INTRODUCTION}

When rock material disintegrates by weathering, the contacts between mineral grains loosen and the porosity increases. The changes become visible first in the appearance, by continuing weathering they become obvious also in the strength of the material and finally they affect the mineral composition. The general hypothesis concerning the progressing weathering is that the strength of rock decreases and water absorption increases. The changes of strength and structure in plutonic rocks, caused by weathering, have been relatively little studied. One reason for this might be that, in spite of the fact that air pollution accelerates the weathering of the building stone material, the plutonic rocks, even in present conditions, are more resistant to the weathering stress of the polluted air than the sedimentary rocks. Instead of measuring exactly the strength of rock, the decreasing of the weight of samples has in most cases been used as an indicator of the susceptibility to weathering. Different forms of weathering have also been studied, but little work has been done on the comparisons between the effectiveness of different weathering processes. The susceptibility to weathering of natural rock material in the laboratory conditions have been studied for example by Griggs (1936), Wiman (1963), Wellman \& Wilson (1965), Martini (1967), Winkler \& Wilhelm(1970), Winkler \& Singer (1972), Winkler (1973), Cooke (1979), Auger (1988), Uusinoka \& Nieminen (1988) and Fitzner (1990).

\section{METHODS}

The effect of some weathering processes as well as their combinations on the strength and porosity of the rock material was examined by exposing small-

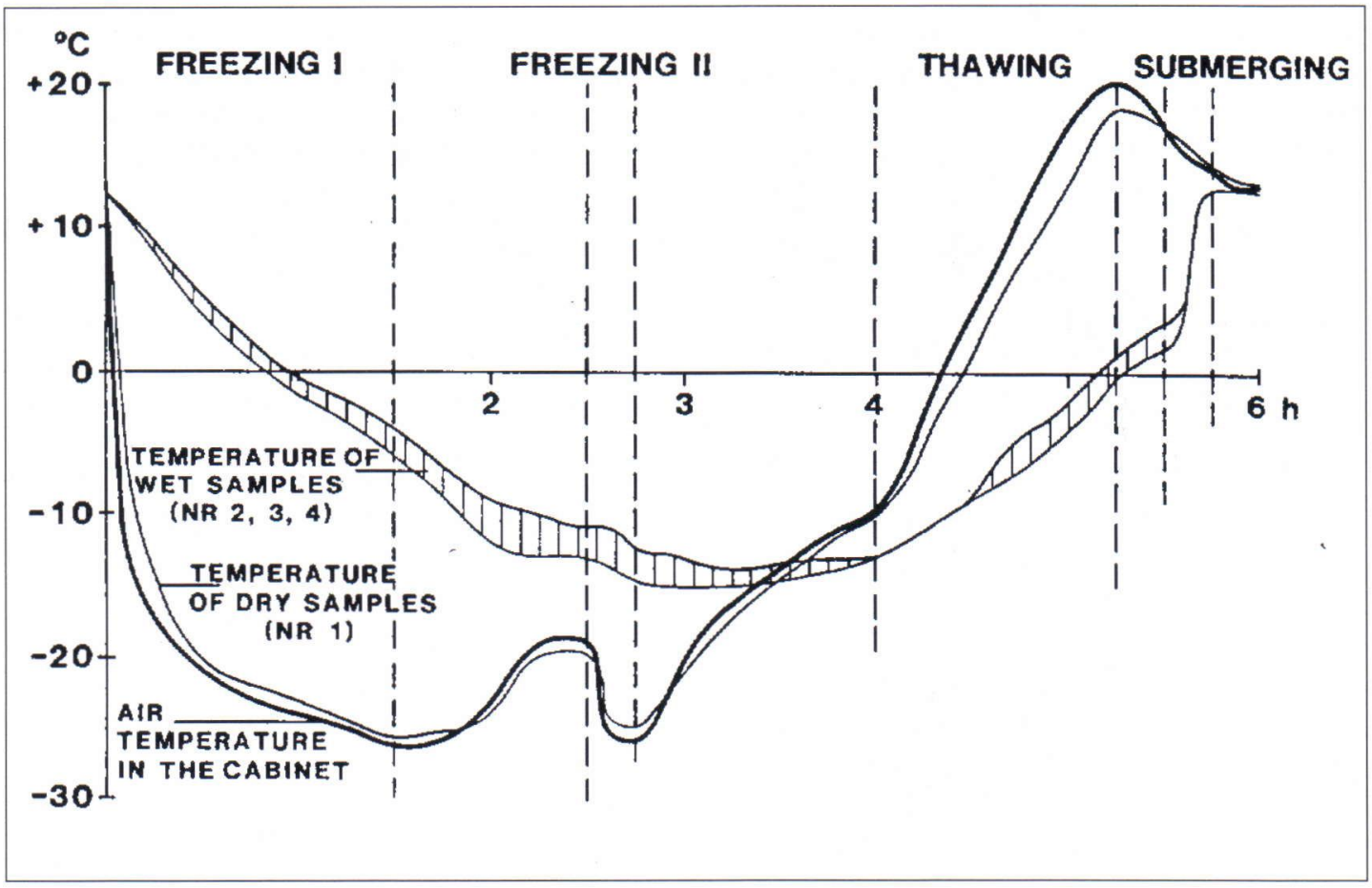

Fig. 1. The variation of temperature in climatic chamber and in samples. 
Table 1. Conditions of the artificial weathering treatment. $R H=$ relative humidity.

\begin{tabular}{|c|c|c|c|}
\hline $\begin{array}{l}\text { Sam- } \\
\text { ple Nr }\end{array}$ & $\begin{array}{l}\text { Temperature } \\
\text { variation }\end{array}$ & $\begin{array}{l}\text { Liquids used in } \\
\text { treatment of samples }\end{array}$ & $\begin{array}{l}\text { Theoretical type of } \\
\text { weathering treatment }\end{array}$ \\
\hline 1 & $-25^{\circ} \mathrm{C}-+18^{\circ} \mathrm{C}$ & $\begin{array}{l}\mathrm{H}_{2} \mathrm{O} \text { (occasional } \\
\text { condensed moisture) }\end{array}$ & $\begin{array}{l}\text { heating and cooling } \\
\text { (physical) }\end{array}$ \\
\hline 2 & $-13^{\circ} \mathrm{C}-+13^{\circ} \mathrm{C}$ & $\mathrm{H}_{2} \mathrm{O}(100 \% \mathrm{RH})$ & frost weathering (physical) \\
\hline 3 & $-13^{\circ} \mathrm{C}-+13^{\circ} \mathrm{C}$ & $\begin{array}{l}\text { Sea salt - solution, } \\
2 \%(100 \% \mathrm{RH})\end{array}$ & $\begin{array}{l}\text { frost weathering }+ \text { salt } \\
\text { weathering }+ \text { solution } \\
\text { (physical + chemical) }\end{array}$ \\
\hline 4 & $-13^{\circ} \mathrm{C}-+13^{\circ} \mathrm{C}$ & $\begin{array}{l}\text { Dilute } \mathrm{H}_{2} \mathrm{SO}_{4}, \\
\mathrm{pH}=1(100 \% \mathrm{RH})\end{array}$ & $\begin{array}{l}\text { frost weathering + hydrolysis } \\
\text { (physical + chemical) }\end{array}$ \\
\hline 5 & constant $+20^{\circ} \mathrm{C}$ & $\begin{array}{l}\text { Sea salt - solution, } \\
2 \%(100 \% \mathrm{RH})\end{array}$ & $\begin{array}{l}\text { salt weathering }+ \text { solution } \\
\text { (physical + chemical) }\end{array}$ \\
\hline 6 & constant $+20^{\circ} \mathrm{C}$ & $\begin{array}{l}\text { Dilute } \mathrm{H}_{2} \mathrm{SO}_{4}, \\
\mathrm{pH}=1(100 \% \mathrm{RH})\end{array}$ & $\begin{array}{l}\text { hydrolysis + solution } \\
\text { (chemical) }\end{array}$ \\
\hline
\end{tabular}

dimensioned samples to artificial weathering in a special climatic cabinet. Besides the temperature variation, some samples were also exposed to the influence of solutions accelerating the weathering. The samples were subjected to six different types of weathering conditions, shown in Table 1. The variation of temperature and the duration of the freeze-thaw cycles are shown in Fig. 1. In case of samples 3 - 4 (rows 3 - 4 in Table 1) each cycle was terminated by immersing the samples in solutions given in Table 1. The samples were examined after 50,150 and 400 freeze-thaw cycles to determine their strength and porosity. Samples 5 and 6 (rows 5 and 6 in Table 1) that had been kept in constant temperature, but exposed to the action of identical solutions, were examined in a similar way at the same time. In this study the solutions and concentrations of liquids with an accelerating influence on weathering were chosen to simulate the climatic stresses to which the building stones are exposed on the industrialized coastal area. The total duration of the weathering experiment was 100 days.
The changes in strength and porosity of the samples were measured by means of uniaxial compressive strength, modulus of rupture, point load index, water absorption and mercury porosimetry. Uniaxial compressive strength was determined according to norm DIN 52 105, except the dimensions of the cubic samples. Modulus of rupture was determined according to norm DIN 52112 and point load index according to ISRM (1985). To determine the rate of water absorption, the samples were first evacuated to a pressure of 0.10 mbar, then immersed in water and finally weighed one hour after the submersion. The total pore volume and the pore size distribution of samples were determined by mercury porosimetry (Brakel van \& Modry, 1981; Gregg \& Sing, 1982).

\section{SAMPLES}

The examined samples were of homogeneous unweathered plutonic rock, the Inari anorthosite, also called Vaskojoki anorthosite (Fig. 2). According 


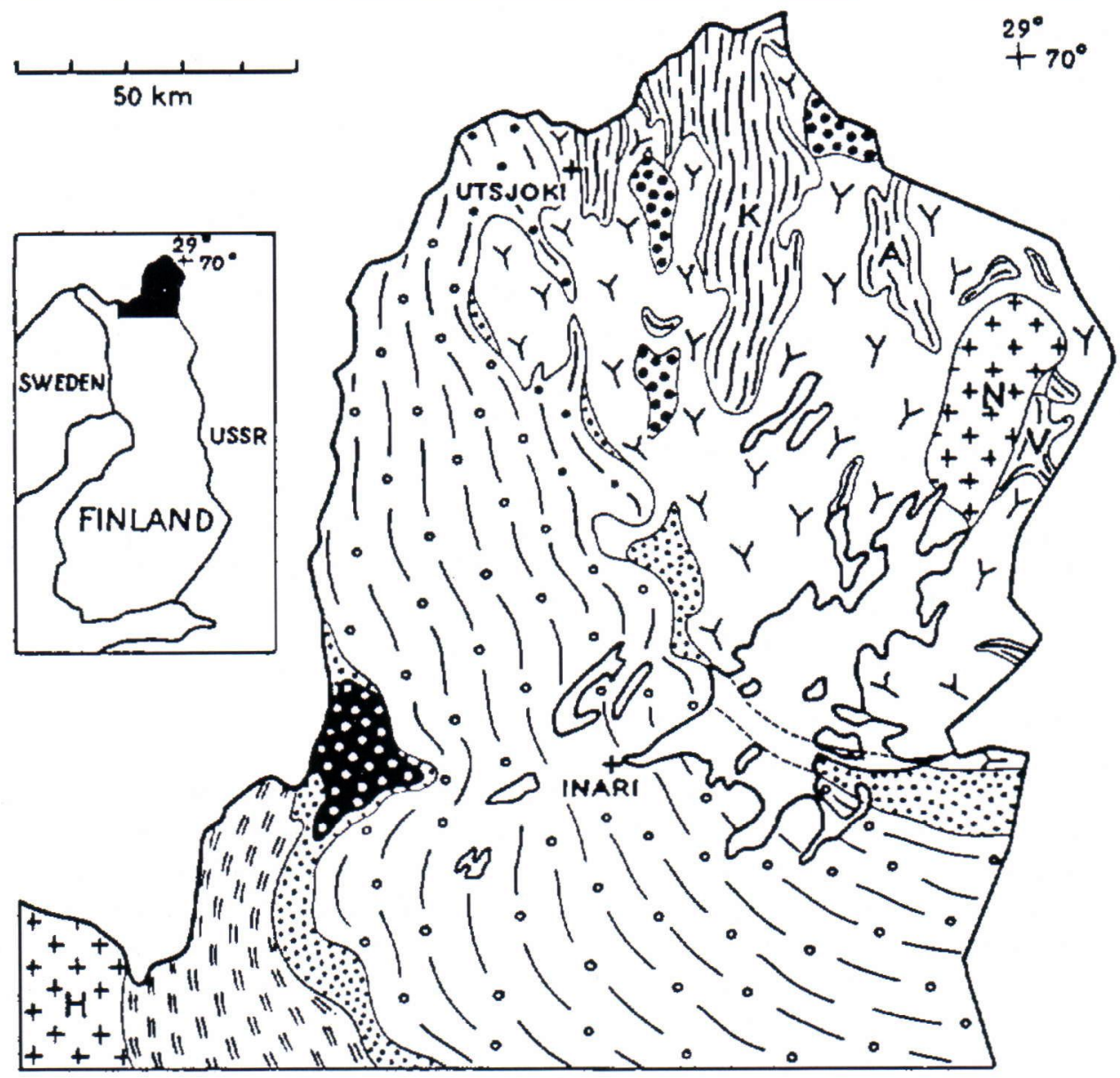

$-x$ Granite gneiss complex

Apukosjörvi (A), Vätsäri (V) and Kuorboaivi (K) schistzones

E- Gronulite complex proper

6 The marginal zones of the granulite complex

$E$ West inari schist zone

6:9: Gobbro massifs of Tsuomasvaaro, Vetsijoki and Petsikkovooro

$\because \because$ Voskojoki onorthosite

$\left[\begin{array}{c}+++] \\ + \pm\end{array}\right]$ Hetto $(H)$ and Kyyneljärvi-Voinospää $(N)$ gronites

Fig. 2. Location of Inari anorthosite (= Vaskojoki anorthosite) and main features of the bedrock in northernmost Finland (Meriläinen 1976). 
to Niini (1967) and Meriläinen (1976) the Inari anorthosite is mostly white or grey, evenly grained (2-3 $\mathrm{mm}$ ) rock that occasionally is porphyritic. It shows light to moderate foliation and is sometimes gneissose as a result of hornblende-bearing streaks. The texture of the Inari anorthosite is hypidiomorphic with plagioclase as the dominant mineral. Plagioclase is in many places zoned with a core of bytownite $\left(\mathrm{An}_{70-80}\right)$ or occasionally even anorthite $\left(\mathrm{An}_{95}\right)$ and a rim of andesine $\left(\mathrm{An}_{30-50}\right)$. The abundance of dark minerals in the rock is about 5 to $10 \%$ hornblende and minor hypersthene or garnet (Table 2). According to Table 3 the strength of Inari anorthosite is well comparable with the most common Finnish granites.

The samples used in the experiments were sawn by a diamant saw into cubic or beam-like forms from stone slabs calibrated to constant thicknesses at stone factory. The most significant exception from the specifications of the norm DIN 52105 was the edge length of $32 \mathrm{~mm}$ in the cubic samples, used for determining the uniaxial compressive strength. The dimensions and the shape of all the other specimens were set according to the specifications of each norm. The number of samples for determination of each strength parameter was 5 10. The freezing capacity of the climatic cabinet
Table 2. Mineral composition of the Inari anorthosite (Meriläinen 1976).

\begin{tabular}{ll|}
\hline & \\
Plagioclase & $84-92 \%$ \\
Hornblende & $5-13 \%$ \\
Augite & $1-5 \%$ \\
& $0-1 \%$ \\
Hypersthene & $0-0.3 \%$ \\
Epidote & $0-0.2 \%$ \\
Garnet & + \\
Zircon & + \\
Titanite & \\
& \\
\hline
\end{tabular}

limited the total weight of samples to about 60 kilograms.

\section{RESULTS}

The experiments showed that the variation of temperature alone neither decreased significantly the strength of the Inari anorthosite nor increased its porosity or water absorption capacity (row 1 in Table 4). The changes in strength and porosity were somewhat greater as the weathering effect was

Table 3. Strength parameters of the Inari anorthosite, determined by the Institute of Engineering Geology, Tampere University of Technology, except the ones signed with * (*= Finnish Stone 1991).

\begin{tabular}{l|l|l} 
& Inari anorthosite & $\begin{array}{l}\text { Finnish granites } \\
\text { in average }\end{array}$ \\
\hline $\begin{array}{l}\text { Uniaxial compressive strength } \\
\text { Modulus of rupture }\end{array}$ & $\begin{array}{l}183 \mathrm{MPa} \\
15 \mathrm{MPa}\end{array}$ \\
$\begin{array}{l}\text { Young's modulus (average) } \\
82000 \mathrm{MPa}\end{array}$ & $\begin{array}{l}18.5 \mathrm{MPa}^{*} \\
56800 \mathrm{MPa}^{*}\end{array}$ \\
$\begin{array}{l}\text { Water absorption } \\
\text { Specific gravity }\end{array}$ & $0.12 \%$ & $0.20 \%$ \\
Los Angeles value & $2.70 \mathrm{t} / \mathrm{m}^{3}$ & $2.71 \mathrm{t} / \mathrm{m}^{3}$ \\
& 39 & 27 \\
Point load index & $8.7 \mathrm{MPa}$ & $8.4 \mathrm{MPa}$
\end{tabular}


Table 4. Changes of strength and water absorption of Inari anothosite during artificial weathering test of 400 freeze-thaw cycles and/or 100 days. Standard deviations of results are given in parentheses. In case of unweatherded material all the parameters in Table 4 don't coincide with the corresponding parameters in Table 3 because of different dimensions of the samples used in determinations.

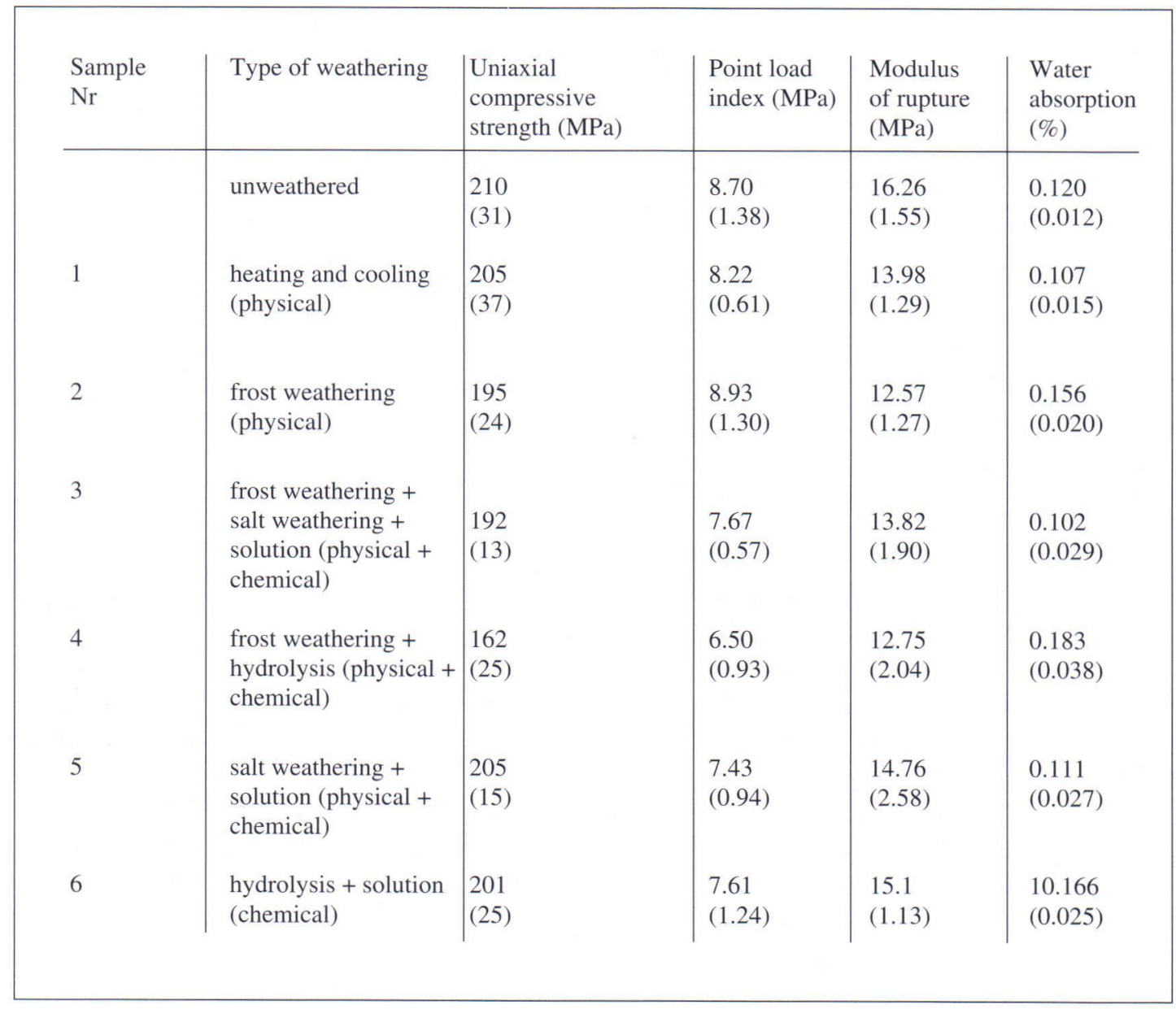

intensified by exposing the specimens to freezing and thawing in $100 \%$ relative humidity (row 2 in Table 4). More than weathering by freezing and thawing alone or by salt crystallization in $2 \%$ sea salt liquid as such, a combination of these methods proved to have a greater influence on the strength and porosity of the sample material (row 3 in Table 4).

The greatest decrease of Inari anorthosite strength was obtained by combining the freezing and thawing cycles with hydrolysis in dilute sulphuric acid (row
4 in Table 4). The weathering effect of this combination proved to be significantly greater than the effect of freezing and thawing or hydrolysis alone (rows 2 and 6 in Table 4). A comparison between the effectiveness of weathering by freezing and thawing and by hydrolysis, shows that in this case the effectiveness of both the methods reaches quite a low level when measured by means of decrease in strength and increase in porosity (rows 2 and 6 in Table 4, Table 6). This means that the weathering effect of freezing and thawing increases 
Table 5. Correlation coefficients between total porosity and individual strength parameters or water absorption. See also Fig. 3.

\begin{tabular}{|c|c|}
\hline & $\begin{array}{l}\text { Correlation } \\
\text { coefficient }\end{array}$ \\
\hline $\begin{array}{l}\text { between porosity and } \\
\text { compressive strength }\end{array}$ & -0.283 \\
\hline $\begin{array}{l}\text { between porosity and } \\
\text { point load index }\end{array}$ & -0.816 \\
\hline $\begin{array}{l}\text { between porosity and } \\
\text { modulus of rupture }\end{array}$ & -0.903 \\
\hline $\begin{array}{l}\text { between porosity and } \\
\text { water absorption }\end{array}$ & +0.497 \\
\hline $\begin{array}{l}\text { between porosity and wate } \\
\text { absorption of samples no } \\
\text { treated with } \mathrm{NaCl} \text { liquid }\end{array}$ & +0.761 \\
\hline
\end{tabular}

significantly by influence of hydrolysis. According to Fig. 3 and Table 5 the correlation between the total porosity and individual strength parameters of Inari anorthosite varies a lot. The changes of weight in samples, caused by weathering, are shown in Table 7.

After 50 or 150 freeze-thaw cycles no remarkable changes in the strength or porosity of the samples was perceived. The measuring of the change in compression strength proved to be the least suitable
Table 7. Loss of weight of the Inari anorthosite during the artificial weathering treatment of 400 freeze-thaw cycles or 100 days respectively

\begin{tabular}{|l|l|l|}
\hline $\begin{array}{l}\text { Sample } \\
\mathrm{Nr}\end{array}$ & Treatmen & $\begin{array}{l}\text { Loss of t } \\
\text { weight (\%) }\end{array}$ \\
\hline 1 & heating and cooling & 0.0061 \\
2 & frost weathering & 0.0385 \\
3 & $\begin{array}{l}\text { frost weathering+ } \\
\text { salt weathering } \\
\text { frost weathering+ } \\
\text { hydrolysis }\end{array}$ & 0.0231 \\
5 & salt weathering & 0.0585 \\
6 & hydrolysis & 0.3273 \\
\hline
\end{tabular}

of all the used methods to illustrate the decrease of strength in the material (Fig. 3, Tables 4 and 5). The bending and the point loading, which load the specimens also with tensile stress, gave a more accurate indication of the slight changes in strength caused by weathering. The increase of the water absorption gave a relatively good illustration of the progress of the weathering, except with the samples exposed to salt water. The salts tend to crystallize in the pores of the rock and thus prevent the penetration

Table 6. Changes in pore size distribution depending on the type of artificial weathering treatment.

\begin{tabular}{|l|l|l|l|l|l|}
\hline $\begin{array}{l}\text { Sample } \\
\mathrm{Nr}\end{array}$ & $\begin{array}{l}\text { Total pore } \\
\text { volume (\%) }\end{array}$ & $\begin{array}{l}\text { Cumulative } \\
\text { pore volume } \\
\varnothing>10 \mu \mathrm{m} \\
(\%)\end{array}$ & $\begin{array}{l}\text { Cumulative } \\
\text { pore volume } \\
2 \mu \mathrm{m}<\varnothing<10 \mu \mathrm{m} \\
(\%)\end{array}$ & $\begin{array}{l}\text { Cumulative } \\
\text { pore volume } \\
\varnothing<2 \mu \mathrm{m}(\%)\end{array}$ & $\begin{array}{l}\text { Median of the } \\
\text { pore diameter } \\
(\mu \mathrm{m})\end{array}$ \\
\hline Fresh & 0.16 & 0 & 50 & 50 & 1.50 \\
1 & 0.39 & 0 & 60 & 40 & 6.79 \\
2 & 0.33 & 75 & 0 & 25 & 43.4 \\
3 & 0.57 & 40 & 45 & 15 & 7.13 \\
4 & 0.70 & 10 & 50 & 20 & 5.47 \\
5 & 0.36 & 40 & 40 & 65 & 0.38 \\
6 & 0.59 & 20 & 15 & & \\
\hline
\end{tabular}




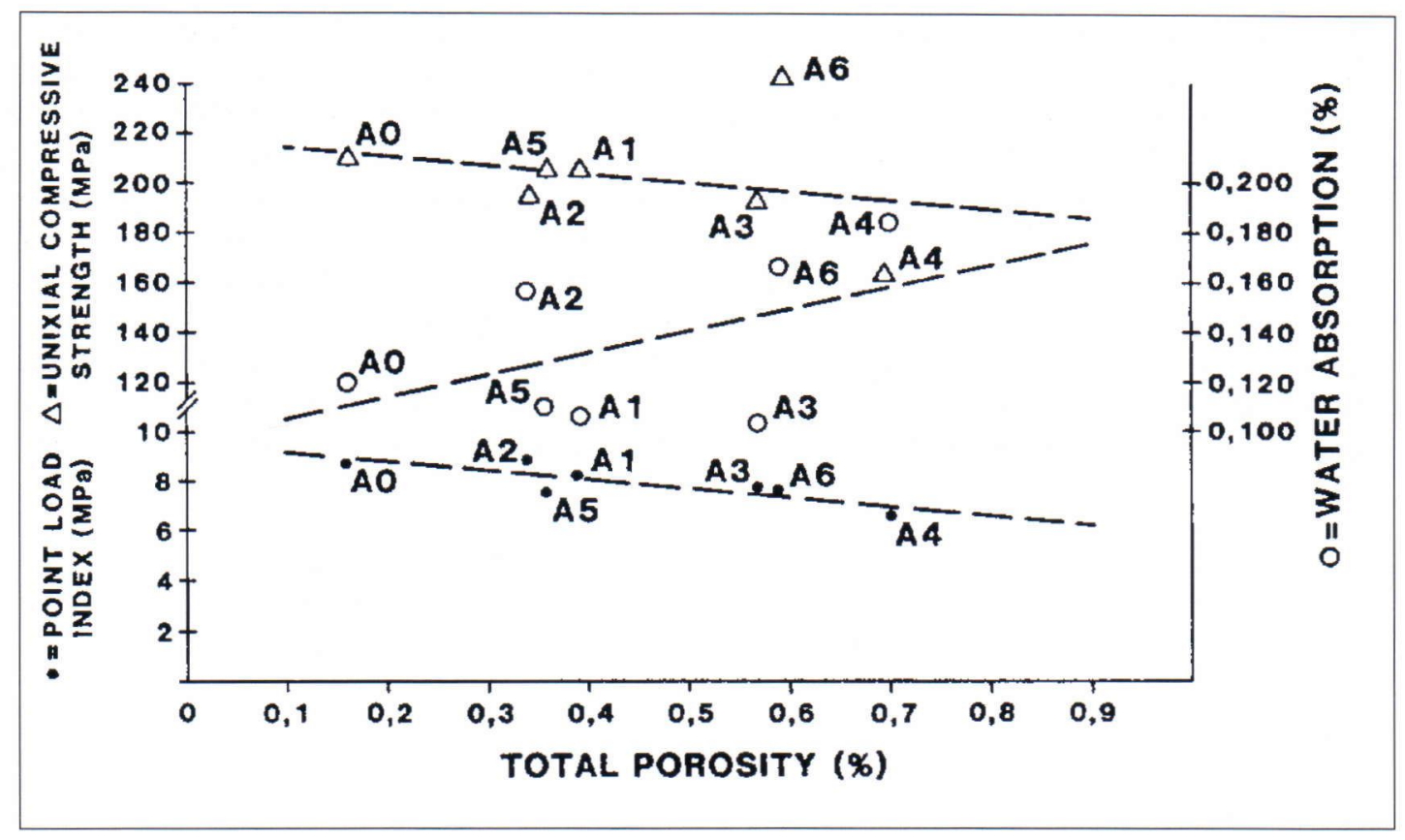

Fig. 3. The correlation between total porosity and some strength parameters of Inari anorthosite.

of the water into the pores. As for the character of the porosity, it was observed that the repeated freezing and thawing increases above all the amount of large pores whereas the hydrolysis increases the amount of small pores (Table 6). According to the thin section analyses it can be stated that the weathering treatment used in this study does not cause perceivable changes in the mineral composition and structure of the Inari anorthosite.

\section{DISCUSSION}

The described method of artificial weathering tests proved not to be effective enough to perfectly characterize the progress of the weathering in case of firm, nearly non-porous plutonic rock. It seems to be characteristic for rocks like Inari anorthosite that the standard deviation of strength parameters is greater than the absolute decrease of strength caused by artificial weathering. It is obvious that the composition of pore water and the rate of saturation have a significant influence on the effect of rock weathering. According to the previous studies it has also been observed that the weathering resistance of Plutonic rocks is high and the weathering is more effective in $100 \%$ relative humidity than in dry conditions (Griggs 1936, Wiman 1963, Martini 1967).

The experimental conditions used in this study were not very favorable to salt weathering. It was not possible to reliably determine the effectiveness of salt weathering in comparison to the frost weathering. This mutual effectiveness has been studied for instance by Cooke (1979). The crystallization of sodium chloride in the pores of the material was not very efficient, due to the Icelandic type of temperature variation in the climatic chamber as well as the high relative humidity around samples.

The repeated freezing and thawing of the pore water proved to increase above all the large diameter porosity in the Inari anorthosite. Similar observations have been made by Fitzner (1990) when measuring the pore size distribution in samples of sandstone with much higher porosity. 
It is difficult to compare the durability against weathering of the Inari anorthosite with the durability of other rock materials because of the lack of appropriate comparison parameters. One possible parameter might be, on the basis of other studies (Griggs 1936, Wiman 1963, Martini 1967, Winkler 1973, Ollier 1984) the change of weight of the samples caused by weathering.

It is also difficult to estimate how the results of these weathering experiments correspond to the length of the weathering period of the building

\section{REFERENCES}

Auger, F., 1988. Simulation accélérée de la dégradation desmatériaux de construction en ambiance aérienne saline. Engineering Geology of Ancient Works, Monuments and Historical sites Vol 2, ed. by Marinos and Koukis. Balkema, Rotterdam, 797-894.

Brakel, J. van \& Modry, S., 1981. Mercury porosimetry: state of the art. Powder Technology Vol 29: 1 - 13. Elsevier.

Cooke, R. U., 1979. Laboratory simulation of salt weathering processes in arid environments. Earth Surface Processes 4, 347-359.

DIN 52 105, 1988. Prüfung von Naturstein. Druckversuch. Deutsche Normen.

DIN 52 112, 1988. Biegeversuch. Deutsche Normen.

Finnish Stone, cataloque. Finnish Stone Producers' Association, Helsinki.

Fitzner, B., 1990. Porosity analysis - A method for the characterization of building stones in different weathering states. Engineering Geology of Ancient Works, Monuments and Historical sites Vol 4, ed. by Marinos and Koukis. Balkema, Rotterdam, 20312037.

Gregg, S. J. \& Sing, K. S. W., (1982). Adsorption, surface area and porosity. Academic Press, London. stone in reality. The effectiveness of weathering depends in natural conditions greatly on the factors of macro and microclimate. It could be estimated, that 400 artificial cycles of freezing and thawing represent at least the effect of 10-20 years of stress put on the outside walls by the climatic conditions in southern Finland. The weathering in a constant temperature during 100 days would probably correspond to a 5-10-year-long period of weathering by rain or some other source of humidity caused to the stone covered building during the warm season.
Griggs, D., 1936. The factor of fatigue in rock exfoliation. Journal of Geology 44, 781-796

ISRM, 1985. Suggested method for determining point load strength. Journal of Rock Mechanics, Mining Science \& Geomechanical Abstracts Vol 22:2, 51-60.

Martini, A., 1967. Preliminary experimental studies on frost weathering of certain rock types from the West Sudetes. Biuletyn Peryglacjalny Vol 16, 147-194.

Meriläinen, $K$., 1976. The granulite complex and adjacent rocks in Lapland, northern Finland. Geological Survey of Finland, Bulletin 281, 126 p.

Niini, H., 1967. The dependence of the relief on the structure and composition of the bedrock in western Inari, Finnish Lapland. Fennia 97:2, 26 p.

Ollier, C., 1984. Weathering. Longman Group Ltd, London, $250 \mathrm{p}$.

Uusinoka, R. P. \& Nieminen, P., 1988. Frost shattering of rocks in the light of porosity. Proceedings of 5 th International Conference on Permafrost Vol 2. Tapir Publishers, Trondheim Norway, 872-875.

Wellman, H. W. \& Wilson, A. T., 1965. Salt weathering, a neglected geological erosive agent in coastal and arid environments. Nature, Vol 205: 4976, 10971098.

Wiman, S., 1963. A preliminary study of experimental frost weathering. Geografiska Annaler Vol 45:2-3, 113-121. 
Winkler, E. M. \& Wilhelm, E., 1970. Salt burst by hydration pressures in architectural stone in urban atmosphere. Geological Society of America Bulletin, 81 (2), 567-572.

Winkler, E. M. \& Singer, P. C., 1972. Crystallization pressure of salts in stone and concrete. Geological Society of America Bulletin, 83 (11), 3509-3513.

Winkler, E. M., 1973. Stone: Properties, durability in Man's environment. Springer-Verlag, Wien, 230 p. 